\title{
Anal Fissure Epidemiology and Related Diseases in Children
}

\author{
Mustafa Yaşar Özdamar, ${ }^{1}$ (1) Erkan Hirik²
}

'Department of Pediatric Surgery, Erzincan Binali Yıldırım University Faculty of Medicine, Erzincan,Turkey ${ }^{2}$ Department of Urology, Erzincan Binali Yıldırım University Faculty of Medicine, Erzincan, Turkey

Submitted: 23.08 .2018 Accepted: 12.10.2018

Correspondence: Mustafa Yaşar Özdamar Erzincan Binali Yıldırım Üniversitesi Tıp Fakültesi, Çocuk Cerrahisi Anabilim Dalı, 24100 Erzincan, Turkey E-mail: mustafayasarozdamar@gmail.com

Keywords: Anal fissure; child; epidemiology; infant.

\begin{abstract}
Objective: After an anal fissure (AF), patients frequently avoid defecation, even if they have diarrhea, due to severe anal pain. This is particularly evident in constipated patients, however the type of functional disease that causes $A F$ is not limited to constipation or persistent diarrhea. The aim of this study was to examine the prevalence and the clinical importance of diseases associated with AF in childhood age groups among young patients with different clinical pictures.
\end{abstract}

Methods: The data related to age, sex, and the accompanying disease of AF patients were collected from a hospital database. Of 7406 patients, 728 were identified and categorized in 6 distinct disease groups associated with AF: constipation; constipation with anal incontinence, urinary incontinence, or anal incontinence and urinary incontinence; infantile colic (IC); and diaper dermatitis (DD). The symptoms of the AF-related diseases were recorded and it was assessed whether AF-related symptoms were reduced after AF treatment.

Results: Of the 728 AF-associated patients of all groups, it was observed that I week after AF therapy, 529 (72\%) experienced a regression in both current disease and AF-related symptoms $(p<0.05 ; r=0.26)$. The improvement in the first week after treatment had a stronger correlation than the improvement in the third week $(r=0.26$ vs. 0.19$)$.

Conclusion: AF was associated with constipation, anal-urinary incontinence, IC, and DD, and was critically important in the targeted treatment of the related illness. The potential presence of AF should be kept in mind when planning the treatment of these 6 functional disorders.

\section{INTRODUCTION}

Anal fissure (AF) is a longitudinal tear or an ulcer in the anoderm of the anal canal distal to the dentate. It typically causes anal pain during defecation that may occur with or without rectal bleeding. AF does not occur spontaneously; the fissure is classified according to causative factors. Prolonged diarrhea or hard stool causing irritation and trauma to the anal canal are the primary and most common causes of AF. Secondary AF can occur in patients following an anal surgical procedure or with inflammatory bowel disease (e.g., Crohn's disease, ulcerative colitis). AF affects all age groups with an equal incidence in both sexes. ${ }^{[1-3]}$

Once the AF has appeared, patients often avoid defecation, even if they have diarrhea, due to severe anal pain, particularly those with constipation. A vicious cycle often begins between the pain and avoiding elimination of stool. AFs are classified into 2 groups: acute (superficial) and chronic fissure (complicated). Anal pain can initiate a spasm of the internal anal sphincter and create high anal pressure, which leads to a reduction in anodermal perfusion and an increase in ischemia in the AF as the event pro- gresses. ${ }^{[1-5]}$ This cycle can also affect adjacent structures. The pain felt in the anal region due to the anatomical closeness of the bladder and urethra to the rectum, as well as similar innervation (S2-S4 spinal nerves) of the urethral and anal sphincters causes dysfunction in both systems simultaneously. Consequently, AF can cause both bowel dysfunction, and indirectly, bladder dysfunction (bowelbladder dysfunction, BBD). The anal and urethral sphincters become affected as a result of rectal stool retention in constipation. Children with constipation and a fear of pain upon defecation may not achieve independent bowel emptying, which then indirectly impacts bladder function. ${ }^{[6,7]}$

From birth to 5 months of age, hepatic synthesis remains immature in infants, with reduced intraluminal bile acids and less efficient absorption of fats and other nutrients. This leads to a difference in the presence of the natural microflora in the gut. The naturally protective Lactobacillus and Bifidobacterium are often replaced by higher levels of Escherichia coli, Clostridium difficile, and Klebsiella. This flora status brings about increased nutrient fermentation, more gas production, and a modified stool feature, which irritates the gut. Therefore, the irritant fecal feature, 
which causes AF, may be present in infantile colic (IC). The etiology of IC is not precisely known; however, in the treatment of IC, it has been recommended that mothers breastfeeding should eliminate potential allergens (milk, eggs, fish, nuts, soy, and wheat) from their diet. Some practitioners have also suggested switching bottle-fed infants to hydrolyzed formulas. However, the literature research is inadequate regarding the role of $A F$ in $I C$ and whether $\mathrm{AF}$ treatment is effective in suppressing IC symptoms. ${ }^{[8-10]}$

Diaper dermatitis (DD) occurs due to irritation in the diaper area, as it is constantly exposed to urine and feces, generally in infants aged 7-12 months (though it may occur at any age), and is generally a Candida infection. Breastfed babies are less likely to experience DD. ${ }^{[1,12]}$ Though the causes and treatment of DD have been described in detail in previous publications, ${ }^{[11,12]}$ enough information has not yet been reported in the literature about whether DD irritation in the perianal region causes AF. While AF, DD, and IC share some clinical features and causes, it is not yet clear what relationships may exist.

The objective of this study was to investigate some of the diseases that cause AF in children, including functional disorders, and any relationship between these diseases and AF.

\section{MATERIAL AND METHODS}

The data of all patients aged up to 16 years who consecutively presented at I outpatient clinic of pediatric surgery between November 2013 and November 2017 and were diagnosed with AF were retrospectively analyzed. Patients with organic diseases of the intestines and anal canal were not included. The study was approved by the Institutional Ethics Review Board for Clinical Research $(2018,24 / 06)$. This was a retrospective investigation of a 3-year period. Patients with incomplete data were not included in the research.

\section{Diagnosis of patients with anal fistula}

Of a total of 7406 patients who presented at the outpatient clinic, 954 (12\%) were diagnosed with AF based on physical examination. The details of patient age, sex, and accompanying AF-related diseases were collected from the database. The symptoms of AF-related diseases were analyzed, as well the result of treatment for the symptoms. AF was primarily characterized by anal itching, rectal bleeding, and painful defecation. ${ }^{[13]}$

\section{Identification of the study groups}

The data analysis revealed that 6 disease groups were diagnostically related to AF: constipation (Group I); constipation with anal incontinence (Group 2), urinary incontinence (Group 3), or anal incontinence and urinary incontinence (Group 4); IC (Group 5); and DD (Group 6).

\section{Diagnostic criteria of the groups}

The following criteria were used to develop a patient his- tory as part of the determination of the cause of AF:

Group I: Constipation ongoing for at least 2 months, including at least 2 of the following at least once a week in children of at least 4 years of age: I) two or fewer defecations per week, 2) at least I episode per week of fecal incontinence after acquisition of toilet training, 3) history of excessive stool retention, 4) history of painful or hard bowel movements, 5) presence of a large fecal mass in the rectum, 6) history of large-diameter stools that may obstruct the toilet, and 7) history of retentive posturing or excessive volitional stool retention. Other possible symptoms are irritability, decreased appetite, and/or early satiety. Concomitant symptoms disappear immediately following defecation of a large stool. ${ }^{[14]}$

Group 2, 3, and 4: When symptoms of patients who meet Group I criteria also included anal incontinence, urinary incontinence (daily or nocturnal), or both anal incontinence and urinary incontinence (bowel-bladder dysfunction; BBD), these patients were included in separate functional disease group (Group 2, 3, and 4, respectively).

Group 5: Infants with IC were defined by 3 symptoms: crying for more than 3 hours per day, more than 3 days per week, and for a period longer than 3 weeks. An essential criterion was that the baby continuously cried in the evening without apparent provocation. ${ }^{[8-10]}$

Group 6: DD patients were diagnosed by examining the baby's diaper area and identifying the eruptions observed. ${ }^{[1,12]}$

\section{Previous diagnosis and treatment history}

Most of the patients (about $80 \%$ ) were referred from other centers and had problems with gas-stool discharge despite previous treatment for IC or DD. The following medications had been used when the patients were brought to the outpatient clinic: oral laxative in Group I; enema and oral laxative in Group 2;[7] anticholinergic for bladder stabilization in Group $3 ;^{[6]}$ laxatives and enema in Group 4; hypoallergenic formula, herbal tea, simethicone, dicyclomine, and methylscopolamine in Group $5 ; ;^{[8,15]}$ and antifungal as well as steroid ointment in Group 6. ${ }^{[1,12]}$

\section{Treatment applied to patients diagnosed with anal fistula}

The conventional therapies for AF of a warm sitz bath, local application of analgesic ointment (lidocaine ointment, Anestol pomade; Sandoz International $\mathrm{GmbH}$, Holzkirchen, Germany), and stool softeners in case of constipation (Lactulose oral, Osmolak oral; Biofarma ILAÇ SAN. ve Ticaret A.Ş., Istanbul, Turkey) were applied.

\section{Statistical analysis}

The statistical analysis of the findings was performed using PASW Statistics for Windows Version 18.0 software (SPSS Inc., Chicago, IL, USA). For fewer than 50 variables, the Shapiro-Wilks test was used to determine normality of distribution. Otherwise, the Kolmogorov-Smirnov test 
was used. A chi-square test was applied to compare frequencies between or within groups. One-way analysis of variance and post-hoc multiple comparisons were conducted to compare age and gender differences between groups. The Spearman correlation test was performed to determine the relationship between AF and groups since because the groups did not indicate a normal distribution. The results were expressed as percentages or mean $\pm S D$, as appropriate.

\section{RESULTS}

In this study, of the $\mathbf{7 4 0 6}$ patients admitted to our outpatient clinic during the study period, 954 (12\%) were diagnosed with AF-related symptoms and allocated to groups. The AF determined in the physical examination was observed in multiple localizations in the anal region. The distribution of age significantly differed in within-group comparisons and between groups, excluding Groups 2 and 4. There was a statistically significant difference in favor of males, other than in Groups 3 and 6. The majority of
AF-related patients were classified as members of Group I (constipation, 44.2\%) and Group 5 (IC, 26\%) $(p<0.05)$ (Table I, Fig. I).

There was almost no difference in the prevalence of $\mathrm{AF}$ between groups $(p=0.05, p$ value that was nearly but not precisely significant). However, the number of the patients with AF within each group was statistically significantly high $(p<0.05)$. Of the 728 AF-associated patients in all of the groups, $529(72 \%)$ had a reduction in both current disease and AF-related symptoms after I week of AF therapy $(p<0.05 ; r=0.26)$. At the 3-week control examination, complete regression of all symptoms was recorded in 609 , which was statistically significant $(p<0.05 ; r=0.19)$, and it should be noted that not all members of the study group returned for this check-up. The improvement noted in the first week after treatment had a stronger correlation than the improvement observed in the third week ( $r=0.26$ vs. 0.19$)$. The distribution of patients with AF in the groups and the rate of decline in the symptoms of the AF-associated groups after AF therapy are displayed in Table 2 and Figure 2.

Table I. The demographic characteristics of the study patients, and between and within-group differences

\begin{tabular}{|c|c|c|c|c|c|c|}
\hline & $\mathbf{n}$ & $\%$ & $\begin{array}{c}\text { Age }^{* *} \\
(\text { Mean } \pm S D)\end{array}$ & $\mathbf{p}$ & $\begin{array}{c}n \\
\text { (Male/Female) }\end{array}$ & $\mathbf{p}$ \\
\hline Group I & 422 & 44.2 & $4.68 \pm 2.89$ & 0.00 & $234 / 188$ & 0.02 \\
\hline Group 2 & 45 & 4.7 & $8.96 \pm 2.19$ & 0.19 & $33 / 12$ & 0.00 \\
\hline Group 3 & 62 & 6.5 & $8.24 \pm 2.54$ & 0.02 & $30 / 32$ & 0.79 \\
\hline Group 4 & 33 & 3.5 & $8.48 \pm 1.41$ & 0.14 & $24 / 9$ & 0.00 \\
\hline Group 5 & 248 & 26 & $3.72 \pm 1.32$ & 0.00 & $154 / 94$ & 0.00 \\
\hline Group 6 & 144 & 15.1 & $5.88 \pm 2.16$ & 0.00 & $80 / 64$ & 0.18 \\
\hline All groups & 954 & 100 & $3.49 \pm 3.58$ & 0.00 & $555 / 399$ & 0.02 \\
\hline
\end{tabular}

(a)

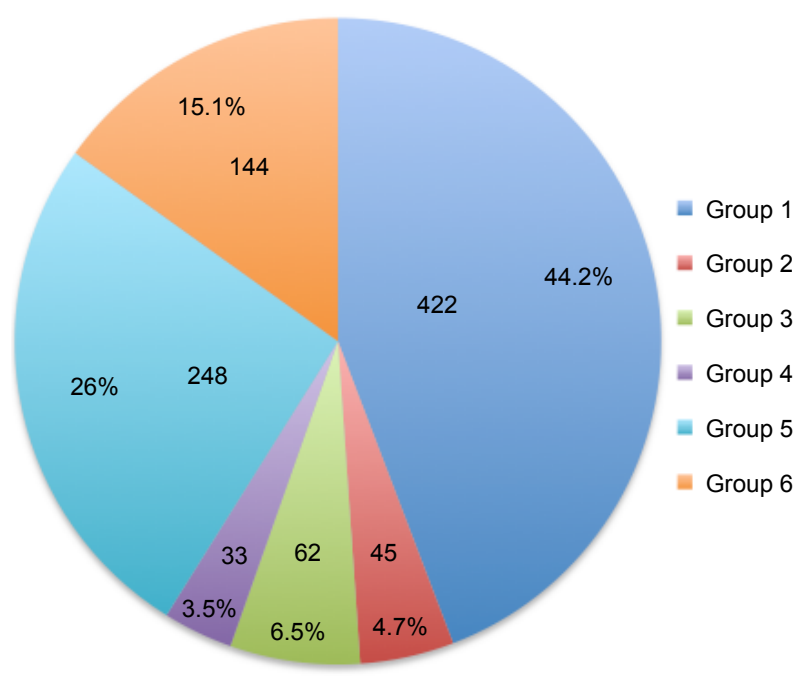

(b)

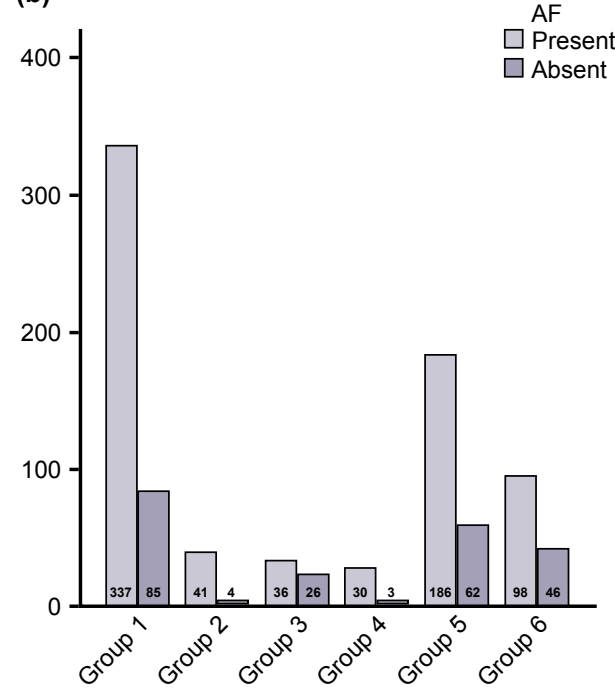

Figure I. Distribution of anal fistula (AF)-related diseases (a) and patients with AF (b) according to group. 
Table 2. The distribution of patients with $A F$ and the rate of decline in the symptoms of the AF-associated groups after AF therapy

\begin{tabular}{|c|c|c|c|c|c|c|c|c|c|c|}
\hline & $\begin{array}{l}\text { AF } \\
\text { (n) }\end{array}$ & $\begin{array}{l}\text { WAF } \\
(\%)\end{array}$ & $\begin{array}{l}\text { WG } \\
\text { (\%) }\end{array}$ & $\mathbf{p}$ & $\begin{array}{c}\mathbf{A F T}^{\prime} \\
\text { (n) }\end{array}$ & $\%$ & $\mathbf{p}$ & $\begin{array}{c}\mathrm{AFT}^{3} \\
\text { (n) }\end{array}$ & $\%$ & $\mathbf{p}$ \\
\hline Group I & 337 & 35 & 80 & 0.00 & 301 & 89 & 0.00 & 318 & 94 & 0.00 \\
\hline Group 2 & 36 & 3.8 & 91 & 0.00 & 23 & 56 & 0.00 & 28 & 68 & 0.00 \\
\hline Group 3 & 41 & 4.3 & 58 & 0.20 & 16 & 44 & 0.00 & 25 & 69 & 0.00 \\
\hline Group 4 & 30 & 3.1 & 91 & 0.00 & II & 36 & 0.00 & 18 & 60 & 0.00 \\
\hline Group 5 & 186 & 19.5 & 75 & 0.00 & 109 & 58 & 0.00 & 136 & 73 & 0.00 \\
\hline Group 6 & 98 & 10.3 & 68 & 0.00 & 69 & 70 & 0.00 & 84 & 85 & 0.00 \\
\hline All groups & 728 & 76 & & $0.05^{*}$ & 529 & 72 & $\begin{array}{c}0.00 \\
\left(r=0.26^{* *}\right)\end{array}$ & 609 & 83 & $\begin{array}{c}0.00 \\
\left(r=0.19^{* *}\right)\end{array}$ \\
\hline
\end{tabular}

*P value that is nearly, but not quite significant. $P<0.05$ : statistically significant. **Spearman correlation test results.

Study groups: Patients with constipation (Group I); constipation and anal incontinence (Group 2), urinary incontinence (Group 3), anal incontinence with urinary incontinence (Group 4); infantile colic (Group 5); and diaper dermatitis (Group 6). (n)AFT: The number of patients with symptomatic improvement after I week (AFT') and 3 weeks $\left(\mathrm{AFT}^{3}\right)$ of the $\mathrm{AF}$ treatment; WAF: Within all $\mathrm{AF}$ groups; WG: Within-group.

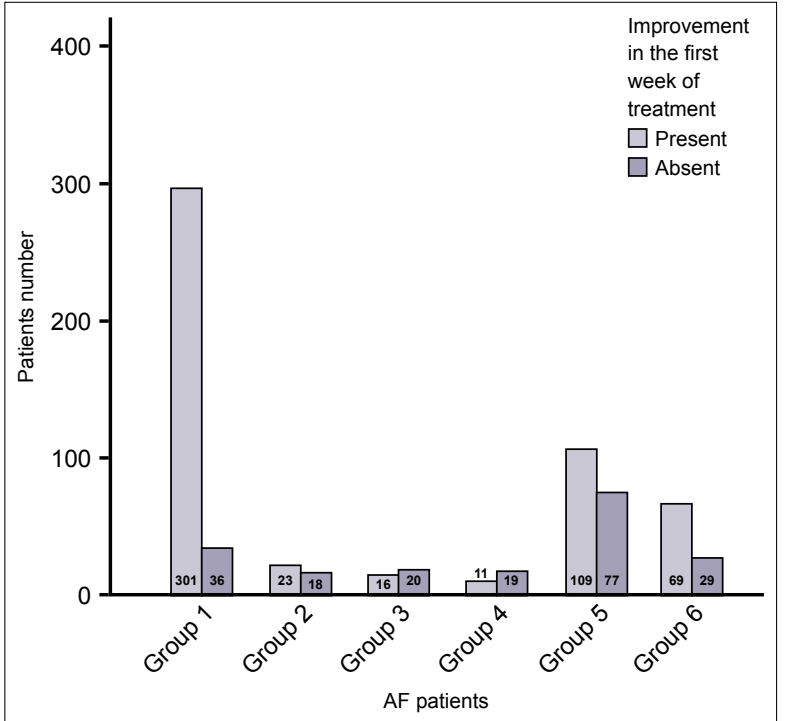

Figure 2. The group distribution of the decline in the patients' symptoms I week after the initiation of anal fistula treatment.

\section{DISCUSSION}

The physiopathological process that causes AF is still not precisely known; however, a relationship between high anal resting pressure as a result of increased internal anal sphincter activity and anodermal ischemia has been put forward recently. ${ }^{[1-5,16]}$ Several causative factors for AF mentioned in the literature were also present in our patients. Functional constipation was present in Groups I through 4 of our study. We found that the occurrence of $\mathrm{AF}$ led to a progression of the disease-related symptoms. One week of AF treatment, however, resulted in significant improvement in both defecation and urinary symptoms. In Groups I through 4, the instance of AF healing was $89 \%$, $56 \%, 44 \%$, and $36 \%$, respectively. The improvement observed in Groups 2 through 4 was statistically significant, but the recovery rate was low. This may have been due to pain in the anal region as a result of anatomical closeness of the bladder and urethra to the rectum. As proposed previously by some authors, similar painful innervation (S2-S4 spinal nerves) of the urethral and anal sphincters may have caused dysfunction in both sphincters simultaneously. In addition, it has been suggested that children with constipation and fear of pain upon defecation may not achieve independent bowel emptying, which would indirectly impact bladder function. ${ }^{[6,7]}$

Zivkovic et al. ${ }^{[17]}$ demonstrated that functional constipation was related to daily urinary incontinence and nocturnal enuresis. Similarly, in our study, BBD was present in Group 3 patients. We found that AF worsened these clinical symptoms and that dramatic healing began within one week after the addition of AF therapy. In the literature, it has been clearly reported that constipation has been associated with dysfunctional voiding and anal and urinary incontinence as well as exacerbating the symptoms of these diseases. However, why AF worsened the clinical picture, or why the expected rate of improvement following treatment is less than that of BBD has not been adequately addressed in publications and reviews. ${ }^{[6,7,17-20]}$

In cases of IC and DD, an irritant intestinal content is observed, rather than the hard stool seen in constipation. [8-12] Children up to about 2 years of age frequently have irritation of the anoderm or diaper region due to the absence of the stable flora or gut microbiota (gut flora) features of adult intestinal content. The altered flora content gives rise to increased nutrient fermentation, more gas production, and the modified stool feature, which irritates the gut. ${ }^{[8-12,21]}$ We detected $75 \%$ and $68 \%$ AF in Groups 5 and 6 (IC and DD groups), while the rate was $19.5 \%$ and $10.3 \%$ within all groups. These rates were statistically significant $(p<0.05)$. Subclassification of IC by symptoms or suspected etiology has been briefly described in previous studies; however, which intervention is most appropriate for an infant with IC has been controversial. IC, which has an incidence of $10 \%$ to $40 \%$ in infants worldwide, is an annoying disease that affects both parents and the patient, 
despite treatment. ${ }^{[8-10,22]}$ We examined this occurrence in relation to $A F$, and found that after $A F$ treatment, the gasfeces discharge of IC patients with AF was regular and comfortable.

The prevalence of dysfunctional voiding has been estimated at $4.2 \%$ to $46.4 \%$ in international sources, and a rate of $9.8 \%$ to $15 \%$ has been reported in our country, depending on the definition used and the study design applied. The enuresis prevalence has been published to be $15 \%$ in our country. Thus far, studies that have examined a relationship between constipation and urinary incontinence have not reported an association with $\mathrm{AF}^{[19,20,23-25]}$ In our study group, the prevalence of urinary incontinence was $6.5 \%$, and urinary incontinence related to constipation with $\mathrm{AF}$ was observed at the rate of $4.3 \%$.

In the literature, although rectal bleeding and gas-stool discharge problems in infants due to AF have been clearly defined, AF in the infant with IC and DD has not been sufficiently investigated. Randomized controlled trials have yielded different results and have only examined dietary or drug treatment methods. ${ }^{[8-12,26,27]}$ We have demonstrated that AF treatment led to a noticeable decrease in the symptoms of these infants and others with similar symptoms, including comfortable gas-feces discharge.

The most significant limitation of the work was the retrospective design and the need to remove patients with incomplete data from the study. For the first time in the literature, we have illustrated that AF, which is caused by functional disorders, may be a part of 6 different clinical entities affecting children. These initial findings should be supported by prospective studies.

\section{CONCLUSION}

We have shown that AF, which was associated with constipation, anal-urinary incontinence, IC, and DD, had critical importance in the targeted treatment of the relating illness. We recommend to keep in mind whether the AF is present while planning the treatment of these six functional disorders.

Source of Funding

None.

Ethics Committee Approval

The study was approved by the Institutional Ethics Review Board for Clinical Research (2018, 24/06).

Informed Consent

Retrospective study.

Peer-review

Internally peer-reviewed.

Authorship Contributions

Concept: M.Y.Ö.; Design: M.Y.Ö; Data collection \&/or processing: M.Y.Ö, E.H; Analysis and/or interpretation: M.Y.Ö, E.H; Literature search: M.Y.Ö.; Writing: M.Y.Ö; Critical review: M.Y.Ö., E.H.
Conflict of Interest

None declared.

\section{REFERENCES}

1. Lund JN, Scholefield JH. Aetiology and treatment of anal fissure. Br J Surg 1996;83:1335-44.

2. Klosterhalfen B, Vogel P, Rixen H, Mittermayer C. Topography of the inferior rectal artery: a possible cause of chronic, primary anal fissure. Dis Colon Rectum 1989;32:43-52.

3. Dykes SL, Madoff RD. Benign Anorectal: Anal Fissure. In: Wolff BG, Fleshman JW, Beck DE, Pemberton JH, Wexner SD, editors. The ASCRS textbook of colon and rectal surgery. New York: Springer Science and Business Media LLC; 2007. p. 178-91.

4. Thomson JPS, Nicholls RJ, Williams CB. Anal Fissure in colorectal diseases. London: William Heinemann Medical Book Limited; 1981. p. 312 .

5. Van Outryve M. Physiopathology of the anal fissure. Acta Chir Belg 2006;106:517-8.

6. Dohil R, Robers E, Verrier Jones K, Jenkins HR. Constipation and reversible urinary tract abnormalities. Arch Dis Child 1994;70:56-7.

7. Chase JW, Homsy Y, Siggaard C, Sit F, Bower WF. Functional constipation in children. J Urol 2004;171:2641-3.

8. Nocerino R, Pezzella V, Cosenza L, Amoroso A, Di Scala C, Amato F, et al. The controversial role of food allergy in infantile colic: evidence and clinical management. Nutrients 2015 7:2015-25.

9. Johnson JD, Cocker K, Chang E. Infantile Colic: Recognition and Treatment. Am Fam Physician 2015;92:577-82.

10. Xinias I, Analitis A, Mavroudi A, Roilides I, Lykogeorgou M, Delivoria $\mathrm{V}$, et al. Innovative Dietary Intervention Answers to Baby Colic. Pediatr Gastroenterol Hepatol Nutr 2017;20:100-6.

11. Stamatas GN, Tierney NK. Diaper dermatitis: etiology, manifestations, prevention, and management. Pediatr Dermatol 2014;31:1-7.

12. Evans SE, Akıncı H, Doğan S, Atakan N. Diaper Dermatitis: A Review of 63 Children. Pediatr Dermatol 2016;33:332-6.

13. Doig CM. ABC of colorectal diseases. Pediatric problems-I. BMJ 1992;305:462-4.

14. Longstreth GF, Thompson WG, Chey WD, Houghton LA, Mearin F, Spiller RC. Functional bowel disorders. Gastroenterology 2006;130:1480-91.

15. Yakut HI, Tunç B. Infantile colic. Turkish Journal of Pediatric Disease 2007;1:57-63.

16. Poh A, Tan KY, Seow Choen F. Innovations in chronic anal fissure treatment: a systematic review. World J Gastrointest Surg. 2010; 27:231-41.

17. Zivkovic VD, Lazovic M, Stankovic I, Dimitrijevic L, Kocic M, Vlajkovic M, et al. Scintigraphy evaluation of the types of functional constipation in children with bowel bladder dysfunction. J Pediatr Urol 2014;10:1111-6.

18. De Paepe H, Renson C, Van Laecke E, Raes A, Vande Walle J, Hoebeke P. Pelvic-floor therapy and toilet training in young children with dysfunctional voiding and obstipation. BJU Int 2000;85:889-93.

19. Sarici H, Telli O, Ozgur BC, Demirbas A, Ozgur S, Karagoz, MA. Prevalence of nocturnal enuresis and its influence on quality of life in school-aged children. J Pediatr Urol 2016;12:e1-6.

20. Haid B, Tekgül S. Primary and Secondary Enuresis: Pathophysiology, Diagnosis, and Treatment. Eur Urol Focus 2017;3:198-206.

21. Mackie RI, Sghir A, Gaskins HR. Developmental microbial ecology of the neonatal gastrointestinal tract. Am J Clin Nutr 1999;69:103545.

22. Gutiérrez-Castrellón P, Indrio F, Bolio-Galvis A, Jiménez-Gutiérrez 
C, Jimenez-Escobar I, López-Velázquez G. Efficacy of Lactobacillus reuteri DSM 17938 for infantile colic: Systematic review with network meta-analysis. Medicine (Baltimore) 2017;96:e9375.

23. Sinha S. Dysfunctional voiding: A review of the terminology, presentation, evaluation and management in children and adults. J Urol 2011;27:437-47.

24. Carman KB, Ceran O, Kaya C, Nuhoglu C, Karaman MI. Nocturnal enuresis in Turkey: prevalence and accompanying factors in different socioeconomic environments. Urol Int 2008;80:362-6.
25. Özkan S, Durukan E, Iseri E, Gürocak S, Maral I, Bumin MA. Prevalence and risk factors of monosymptomatic nocturnal enuresis in Turkish children. Indian J Urol 2010;26:200-5.

26. Jirapinyo P, Densupsoontorn N, Kangwanpornsiri C, Pongdetudom $\mathrm{K}$. No difference in prevalence of anal fissure among infants who are breast-fed, formula-fed and mixed-fed. J Trop Pediatr 2011;57:499500.

27. Garrison MM, Christakis DA. A systematic review of treatments for infant colic. Pediatrics 2000;106:184-90.

\section{Çocuklarda Anal Fissürün Epidemiyolojisi ve Ilişkili Olduğu Hastalıklar}

Amaç: Anal fissür (AF) başladıktan sonra, kabızlığı olanlarda daha belirgin olan şiddetli anal ağrı nedeniyle, hastalar ishal olsalar bile defekasyondan kaçınırlar. AF'ye neden olan fonksiyonel hastalığın tipi, kabızlık veya ishal ile sınırlı değildir. Bu çalısma, tüm çocukluk çă̆ı yaş gruplarında AF ile ilişkili hastalıkların prevalansını ve klinik önemini, farklı klinik tablolarla açıklığa kavuşturmayı amaçlamıştır.

Gereç ve Yöntem: Hastaların yaşı, cinsiyeti ve $A F$ ile ilişkili hastalıkları veri tabanından toplandı. Yedi bin dört yüz altı hastadan $A F$ ile ilişkili altı farklı hastalık grubu belirlendi: I. kabızlık, 2. anal inkontinans, 3. üriner inkontinans, 4. anal inkontinansla birlikte üriner inkontinans, 5. infantil kolik (IC) ve 6. diaper dermatit (DD). AF ile ilişkili hastalıklarda semptomları ve AF tedavisinden sonra AF ile ilişkili semptomların gerileyip gerilemediğini belirledik.

Bulgular: Anal fissür tedavisinden bir hafta sonra, tüm grupların AF ile ilişkili 728 hastasından 529'unda (\%72) hem mevcut hastalıkta hem de $A F$ ile ilişkili semptomlarında azalma vardı $(p<0.05, r=0.26)$. Tedaviden sonraki ilk haftadaki iyileşme üçüncü haftadaki iyileşmeden daha güçlü bir korelasyona sahipti ( $r=0.26$ 'ya karşlık 0.19$)$.

Sonuç: Kabızlık, anal-üriner inkontinans, IC ve DD ile ilişkili AF'nin, ilişkili olduğu hastalığın hedeflenen tedavisinde kritik öneme sahip olduğunu gösterdik. Bu altı fonksiyonel hastalığın tedavisini planlarken AF’nin mevcut olup olmadığını göz önünde bulundurulmasını öneriyoruz.

Anahtar Sözcükler: Anal fissür; çocuk; epidemiyoloji; süt çocuğu. 